\title{
Evaluation of temporal processing skills in individuals with normal hearing
}

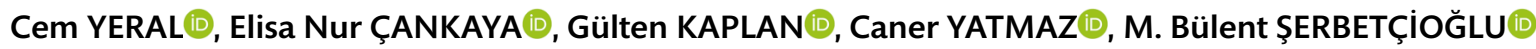 \\ İstanbul Medipol Üniversitesi Sağlık Bilimleri Fakültesi, Odyoloji Bölümü, İstanbul, Türkiye
}

\section{ABSTRACT}

Objective: In a cumulative perspective, the aim of this study is to perform Frequency Pattern Test (FPT), Duration Pattern Test (DPT) and Gap In Noise (GIN) Test in order to determine descriptive values of these tests to evaluate central auditory processing on the individuals' with normal hearing.

Material and Methods: A total of 52 participants, as of 28 women and $24 \mathrm{men}$, with normal hearing, within the age range of 20 to 55 were included in the study. Otoscopic examination, pure tone audiometry and FPT, DPT GIN Test which are central auditory processing tests, were performed on the participants who meet the criteria of the study and voluntarily agreed to participate in the study.

Results: Descriptive values were obtained as an average of $78 \%$ in FPT, $92.11 \%$ in DPT, an average of $61.22 \%$ in GIN Test and an average of $6.34 \mathrm{~ms}$ in Gap Detection Threshold

Conclusions: It is thought that the obtained descriptive values will contribute to the clinics and the literature.

Keywords: Auditory temporal tests, central auditory processing, duration pattern test, frequency pattern test, gap in noise test öz

\section{Normal işiten bireylerde temporal işlemleme becerilerinin değerlendirilmesi}

Amaç: Bu çalışmanın amacı, normal işitmeye sahip bireylerde santral işitsel işlemlemeyi değerlendirmek için Frekans Paternleri Testi, Süre Paternleri Testi ve Gürültüde Boşluk Tanıma Testi uygulamak ve bu testlerin tanımlayıcı değerlerini belirlemektir.

Gereç ve Yöntemler: Çalışmaya normal işitmeye sahip, 20-55 yaş arası 28'i kadın 24'ü erkek olmak üzere toplam 52 katılımcı dahil edilmiştir. Çalışmanın kriterlerini karşılayan ve gönüllü olarak çalışmaya katılmayı kabul eden katılımcılara öncelikle otoskopik muayene, saf ses odyometrisi ardından merkezi işitsel işlemleme testleri olan Frekans Paternleri, Süre Paternleri, Gürültüde Boşluk Tanıma testleri uygulanmıştır.

Bulgular: Tanımlayıcı değerler, Frekans Paternleri Testinde ortalama $\% 78$, Süre Paternleri Testinde ortalama \%92.11, Gürültüde Boşluk Tanıma Testinde ortalama \%61.22 ve Boşluk Tespit Etme Eşiğinde $6.34 \mathrm{~ms}$ olarak elde edilmiştir.

Sonuç: Elde edilen tanımlayıcı değerlerin kliniklere ve literatüre katkı sağlayacağı düşünülmüştür.

Anahtar Sözcükler: Frekans paternleri testi, gürültüde boşluk tanıma testi, işitsel temporal testler, merkezi işitsel işlemleme, süre paternleri testi

Cite this article as: Yeral, C., Çankaya, E.N., Kaplan, G., Yatmaz, C., Serbetçioğlu, M.B. (2021). Evaluation of temporal processing skills in individuals with normal hearing. Turk J Audiol Hearing Res, 4(3):69-77.

\section{INTRODUCTION}

The Central Auditory System is a complex system which consists of a set of different nuclei. It begins in the cochlear nucleus, continues with superior olivary complex, lateral lemniscus, inferior colliculus, medial geniculate body and auditory cortex (Zhang, G.W. et al., 2018). The decisive feature of Auditory System is an extraordinary temporal precision (Long, P. et al., 2018). Central auditory processing is the perceptual processing of auditory signals in the central nervous system and neurobiological mechanisms, which are the infrastructure of electrophysiological auditory potentials.
Central auditory processing includes sound localization and lateralization; auditory discrimination, auditory pattern recognition, temporal characteristics of auditory signals (Fattahi, J. et al., 2019). Disturbance in the auditory processing function is defined as Central Auditory Processing Disorder (CAPD) although peripheral hearing system and cognitive skills are normal (Göv Aktan, K., 2015). Individuals with CAPD have difficulty in hearing and/or understanding auditory information, even if their auditory thresholds are normal. They may have several difficulties, such as understanding speech in noisy 
environments, difficulty in following instructions, problems of discriminating similar speech sounds, and often requesting the repetition of verbal information (Volpatto, F.L. et al., 2019). Although there are various tests to evaluate central auditory processing, there is no single test battery for all features of central auditory processing. So in this case, it is appropriate to determine the most convenient test battery according to the case and situation(Tuz, D. et al., 2020).

Temporal processing is defined as the perception of sound or as the change in sound within a limited or defined time frame. Furthermore, temporal processing is the component that underlies many auditory processing abilities (Marshall, E.K. et al., 2017). Temporal processing is examined in four subtitles as temporal sequencing, temporal resolution, temporal integration and temporal masking(Gürses, E. et al., 2020).

Temporal sequencing refers to the ability of accurately detecting multiple audio signals based on their order of presentation. Since dynamic acoustic cues change in a fluent speech, it has a facilitation function in speech understanding. So temporal sequence is considered to be a important skill for speech recognition skills (Fitzgibbons, P.J. et al., 1996).Furthermore, we can spot that Frequency Pattern Test being firstly described in 1971 by Pinheiro and Ptacek. The participants are asked to rank the sounds in two different frequencies in accordance to their order of presentation. It is one of the mostly used tests in clinical practice due to its ease of application, sensitivity and specificity (Gürses, Türkyılmaz, \& Sennaroğlu, 2020). Also, researchers show that FPT is resistant to peripheral hearing loss as long as the stimuli are audible and sensitive to lesions of the cerebrum, corpus callosum, and brainstem (Balzan, P. et al., 2017). On the other hand, DPT was developed by Musiek in 1990 (Mustek, Baran, \& Pinheiro, 1990). DPT is sensitive to cerebral lesions, that also evaluates duration discrimination, temporal sequencing and linguistic labeling processes (Balzan, P. et al., 2017; Musiek, F.E., 1994). Both cerebral hemispheres need to resolve the pattern feature of the auditory signals and give a verbal response. While the right hemisphere is responsible for recognition of acoustic contour and patterns, the left hemisphere is dominantly responsible for speech, language and temporal sequencing (Musiek, F.E., 1994).

Temporal resolution can be defined as the potential of the auditory system to respond to rapid changes in an auditory stimulus (Shinn, J.B. et al., 2009). The Gap in Noise test was developed by Musiek et al. in 2005 to evaluate temporal resolution (Musiek et al., 2005). Temporal resolution is typically assessed by psychoacoustic measurements known as gap detection (Gilani, V.M. et al., 2013). Gap detection is a common and well-studied measure of auditory temporal resolution. In the traditional gap detection task, the listener needs to detect a brief temporal gap embedded in a stimulus. The shortest detectable gap has been estimated as the gap detection threshold using either speech or non-speech stimuli. The gap detection threshold is known to depend on a variety of stimulus characteristics such as stimulus level, stimulus bandwidth, modulation features, spectral and temporal complexity, and uncertainty (Jung, Y.K. et al., 2020). The purpose of this procedure is to determine the minimum gap that a listener can detect. This is also known as gap detection threshold (Shinn, J.B. et al., 2009). Gap detection is also related to speech perception in noise. In normal life, background noise can show a change in terms of intensity. Speech cues can be detected when the noise level is low (Geffner, D., 2007).

Temporal integration investigates how sound energy gets integrated into the auditory system over time (Yaral1, M., 2011). Temporal masking can be defined as the ability to mask another sound that precedes or follows a sound itself (Marshall, E.K. et al., 2017).

In a cumulative perspective, The aim of this study is to perform Frequency Pattern Test (FPT), Duration Pattern Test (DPT) and Gap In Noise (GIN) Test in order to determine descriptive values of these tests to evaluate central auditory processing on the individuals' with normal hearing. It is envisaged descriptive values that obtained will not only contribute to audiology clinics but also will contribute to the relevant literature.

\section{METHOD}

\section{Participants}

A total of 52 participants, as of 28 women and 24 men, with normal hearing, within the age range of 20 to 55 were included in the study. Indeed, all the participants were informed in regarding the aims of the study, duration of the tests and the nature of the tests beforehand.

\section{The criteria were as follows:}

- Aged between 20 to 55 (Gürses, Türkyılmaz, Kalaycıoğlu, et al., 2020),

- Normal otoscopic findings,

- $\leq 25 \mathrm{~dB}$ HL of hearing thresholds at octave frequencies from 250 to $8,000 \mathrm{~Hz}$

The criteria for exclusion from individuals are determined as follows:

- Physical or emotional symptoms that may prevent the individual from performing the tests,

\section{Procedure}

The participants included in the study were divided into 20-30, 31-40, 41-55 age groups (Gürses, Türkyılmaz, Kalaycioğlu, et al., 2020). There are 18 people in the $20-30$ and 31-40 age groups, and 16 people in the $41-55$ age group. The total number of participants required in the study was determined by GPOWER 3.1. (Erdfelder, FAul, Buchner, \& Lang, 2009). The tests were performed between the dates of 25.10.2019-12.03.2020 in the audiology clinic. In addition, some audiological tests 
were applied to the participants who agreed to take part in the study. Central auditory processing tests were performed on the individuals with normal hearing, as in accordance with audiological examination.

\section{Assessment Parameters}

Otoscopic examination, pure tone audiometry and Frequency Pattern, Duration Pattern, Gap In Noise tests which are central auditory processing tests, were performed on the participants who meet the criteria of the study and voluntarily agreed to participate in the study.

\section{Audiological assessment}

In order to determine whether there is any obstacle to perform the pure tone audiometry test to the individuals participating in the study, an ear examination was performed with Heine Mini3000 model otoscope. Initially, pure tone audiometry was performed in the silent cabin using the Interacoustics AC40 audiometer (Interacoustics Co., Middelfart, Denmark). Pure tone stimuli were delivered by TDH-39P supra-aural earphones (Telephonics Co., New York, NY, USA) at octave frequencies ranging from $250 \mathrm{~Hz}$ to $8000 \mathrm{~Hz}$. Bone conduction stimuli delivered via $\mathrm{B} 71 \mathrm{~W}$ bone vibrator (RadioEar, America) at octave frequencies of $500 \mathrm{~Hz}, 1000 \mathrm{~Hz}, 2000 \mathrm{~Hz}$ and $4000 \mathrm{~Hz}$. Having performed pure tone audiometry, speech audiometry tests were also accomplished, i.e. speech recognition threshold and speech discrimination score tests.

\section{Evaluation of central auditory processing}

Frequency pattern test, duration pattern test and gap in noise test were performed. There were intervals between each tests depending on the request of the participants. Central auditory processing tests which are used in our study were created using Praat 6.0.33. For determination of stimulus parameters the method by Musiek F. E. et al. was used and prepared test materials were saved to the computer which was connected to the AC40 audiometer (Musiek, 1994). The sounds were delivered through JBL speaker. The tests were carried out in the free field condition, with the speaker at 0 azimuth and 1 meter, at the most convenient condition for participants.

Tests were carried out at the most comfortable hearing level of the participants. Signals were presented at $40 \mathrm{dBHL}$ above the speech reception threshold of the participants.

\section{Frequency pattern test}

For the Frequency Pattern Test, three different acoustic signals were presented to the participants, in which the two tones are on the same frequency; the third tone is in a different frequency; the high frequency pure tone signal is $1122 \mathrm{~Hz}$ and the low frequency tone is $880 \mathrm{~Hz}$. The duration of each tone was $200 \mathrm{~ms}$ and the interstimulus interval was $150 \mathrm{~ms}$ (See Figure 1) (Musiek, F.E., 1994). Rise and fall times were $10 \mathrm{~ms}$. There were six possible combinations of tones (LLH, LHL, LHH, HLH, HLL and HHL). Participants were asked to sort their voices verbally according to their frequency and order of presence, by selecting them from the computer screen / keyboard keys or humming.

Participants were informed before the test that the trial auditory stimuli was going to be excluded for the scoring. Stimuli to be presented to the participant were in triple rows, making 40 stimuli in total. The participants were requested to determine pitch and the order of presentation (eg. Low-High-Low'). Also, the testing was carried out at the most comfortable hearing level of the participants. A result percentage is calculated based on the responses of the participants. (eg 32 correct answers out of 40 stimuli: \%80). For Frequency Pattern Test, normal test results for individuals aged 11 and over are accepted to be $75 \%$ and above (Musiek, F.E., 2002).

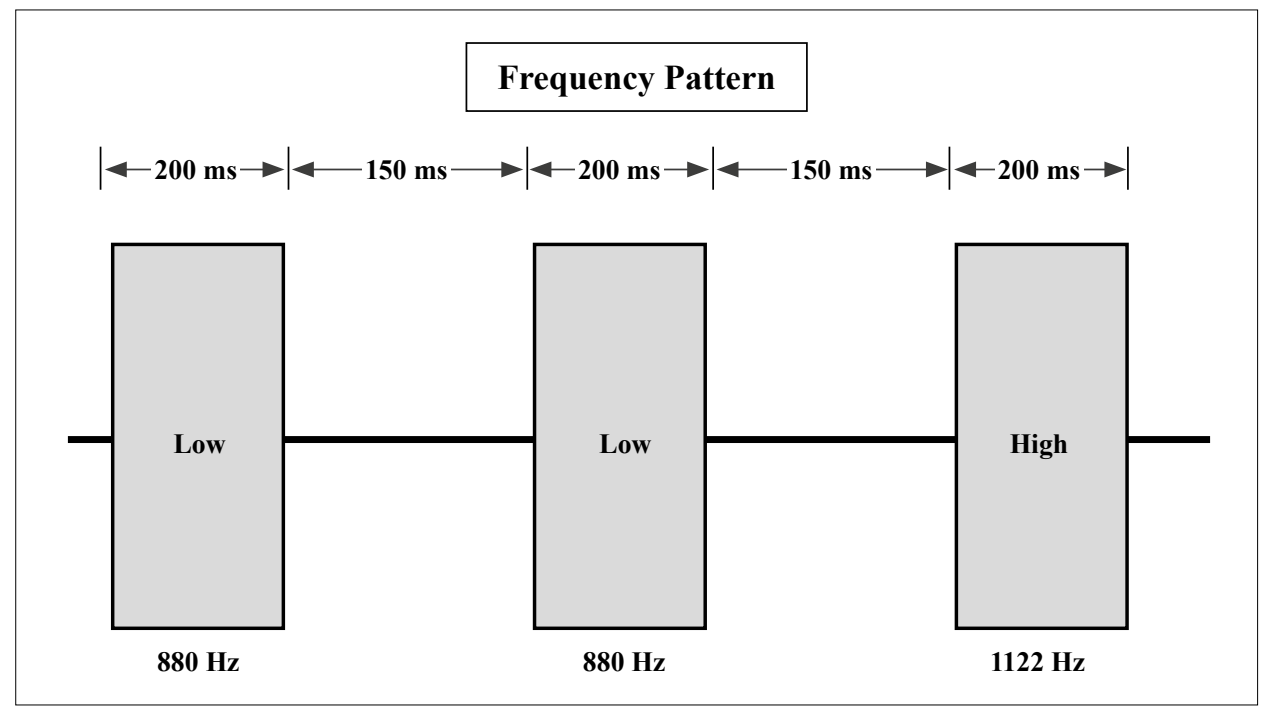

Figure 1. Properties of Stimuli Used in Frequency Pattern Test 


\section{Duration Pattern Test}

Regarding the method used by Musiek (Musiek, F.E., 1994); three stimuli at a frequency of $1 \mathrm{kHz}$ were presented in a row. Stimuli were the same in terms of sound intensity and frequency, but they differed in duration. One of the stimuli presented was definitely different from the others. The duration of long stimuli was $500 \mathrm{~ms}$ and $250 \mathrm{~ms}$ for the short, interstimulus interval was $300 \mathrm{~ms}$ (See. Figure 2.). The rise and fall time of the stimuli is $10 \mathrm{~ms}$.

Stimuli presented to the participants were at a level of the most comfortable hearing level for individuals. Two different stimuli creates a total of six different patterns in the event of combinations in triple rows. These patterns are shown in Table 1.

In our study, participants were informed before the test and auditory stimuli were presented for trial purposes in order not to

Table 1. A Sample of Timing Properties and Expected Responses for DPT

\begin{tabular}{|l|l|}
\hline Stimulus Times (ms) & Answer Expressions \\
\hline $500-500-250$ & Long - Long -Short \\
\hline $500-250-250$ & Long - Short - Short \\
\hline $500-250-500$ & Long - Short - Long \\
\hline $250-500-500$ & Short - Long - Long \\
\hline $250-250-500$ & Short - Short - Long \\
\hline $250-500-250$ & Short - Long - Short \\
\hline
\end{tabular}

be included in the scoring. After the trial test, the stimuli were presented to the participant in triple rows, 40 stimuli in total. The participants were requested to say the auditory stimuli they hear according to duration and order of presentation (eg 'LongShort-Long'). The test performed at the most comfortable hearing levels for the participants.

There are two scoring systems for the DPT calculations (Yaral1, 2011). Scoring systems are shown in Table 2. However, in this study, scoring was performed only according to the DPT Rev (-) scoring system.

Table 2. A Sample For Two Different Scoring Systems Performed Using DPT Scoring System

\begin{tabular}{|l|c|c|c|}
\hline $\begin{array}{l}\text { Pattern } \\
\text { (L:Long,S:Short) }\end{array}$ & $\begin{array}{c}\text { Individual's } \\
\text { answer }\end{array}$ & $\begin{array}{c}\text { DPT Rev } \\
(-)\end{array}$ & $\begin{array}{c}\text { DPT Rev } \\
(+)\end{array}$ \\
\hline S - L - S & S - L - S & + & + \\
\hline L - S - L & S - L - S & - & + \\
\hline L - L - S & L - S - L & - & - \\
\hline
\end{tabular}

DPT Rev (+): The type of score calculated by accepting the reverse answered patterns correctly.

DPT Rev (-): The type of score calculated by accepting the reverse answered patterns incorrectly. In a study by Gürses (Gürses, E. et al., 2020) DPT values of normal hearing individiuals were found to be $\% 82.52$ and higher In our study, presented values were used as a reference.

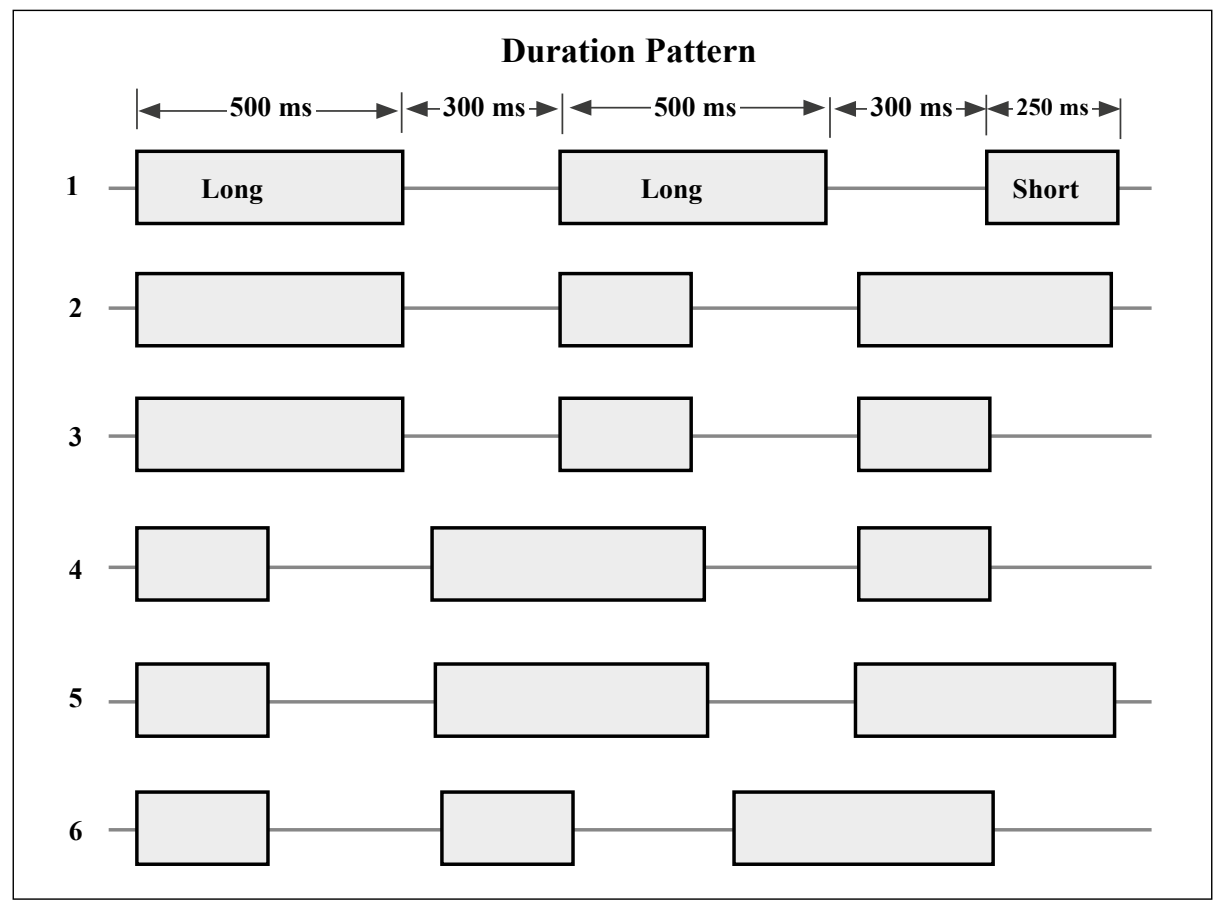

Figure 2. Properties of Stimuli Used in Duration Pattern Test 
Gap In Noise Test

The GIN test consists of a compact disc recording presented with a clinical audiometer. The stimulus in the test is presented as the form of zero to three gaps in a 6 second white band noise segment. Gap times were in the range of 2-20 $(2,3,4,5,6,8,10,12,15,20)$ milliseconds (Hoover, E. et al., 2015). These ten different stimuli which differed from each other only in duration were used 6 times each in the test. There are sixty sets in total. There is a 5 seconds gap between each 6 seconds white noise segment. (See Figure 3).

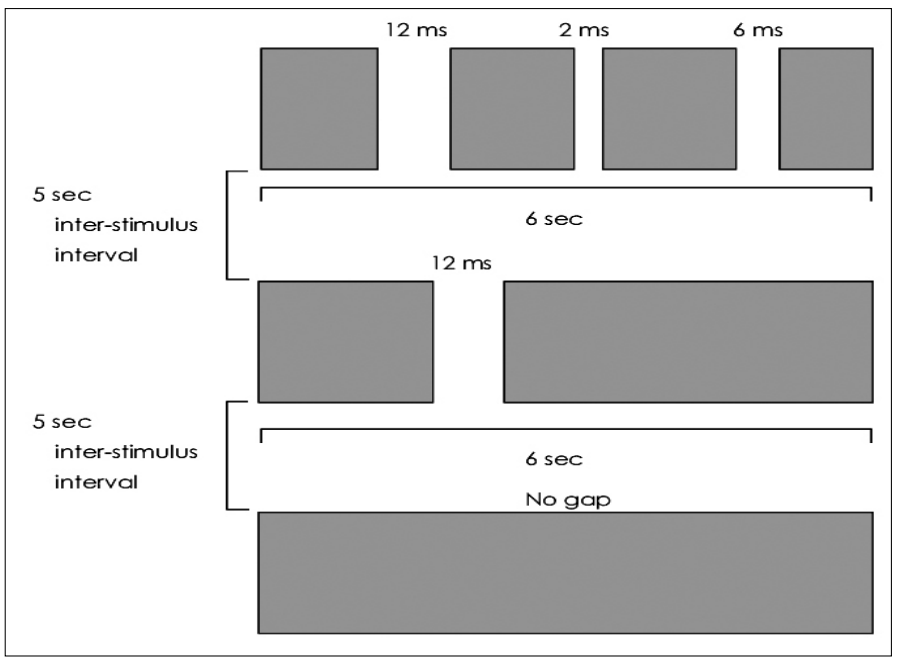

Figure 3. A Sample Test Stimuli Used in Gap in Noise

Participants received an explanation regarding the test procedure before the test. To familarize, a trial test was carried out for each participant. The task of the listener is to point out or verbally express each gap that he or she notices. There are two different paradigms in the test. These are; general percentage score and gap detection threshold. The gap detection threshold is found in milliseconds, where it can detect at least 4 of the 6 gaps. The general percentage score is calculated based on the number of gaps that can be noticed from 60 gaps.

Normal values are 6 milliseconds or less for the gap detection threshold and are expressed as 54\% and better for the general percentage score (Paulovicks, J., 2008). This presented value was used as a reference value in our study.

\section{Data Analysis}

The data analysis of our study was done by, "Statistical Package for Social Sciences" (SPSS) Version 20.00 (SPSS inc. Chicago, IL, USA) as using a statistics program. In descriptive statistical information, mean and standard deviation (Mean \pm SD) are given. The statistical significance level was accepted as 0.05 in all analysis results. Based on these reference values, "One Sample t Test" was used to analyze the test results. Another hypothesis of the study required correlation test analysis. Since the number of participant is greater than 50, "KolmogorovSmirnov Test" was used for normality investigation. Because the data was found to be not normally distrubuted according to
Kolmogorov-Smirnov Test , "Spearman Correlation Test" was used in the correlation analysis.

\section{Ethical Committee Approval Number}

Study titled "Evaluation of Temporal Processing Skills In Individuals with Normal Hearing" was approved by NonInterventional Clinical Research Ethics Committee with the number of 766 dated with 09/10/2019.

\section{RESULTS}

\section{Demographic Information}

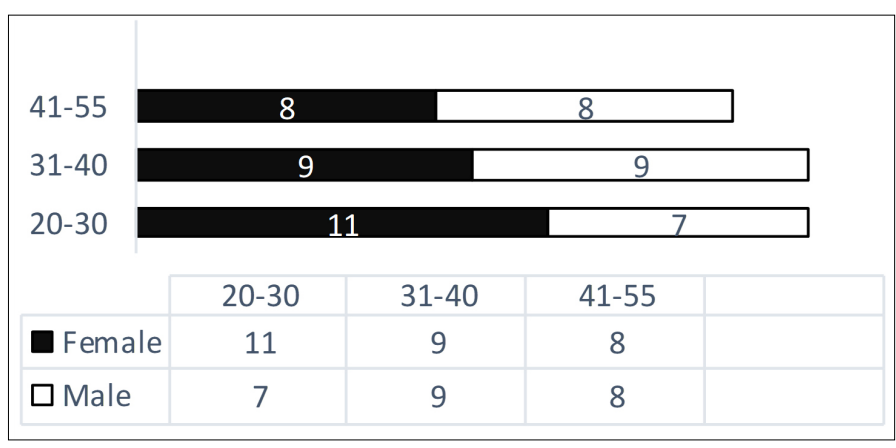

Figure 4. Gender Distribution By Age Groups

\section{Comparison of Central Auditory Processing Tests with Reference Values}

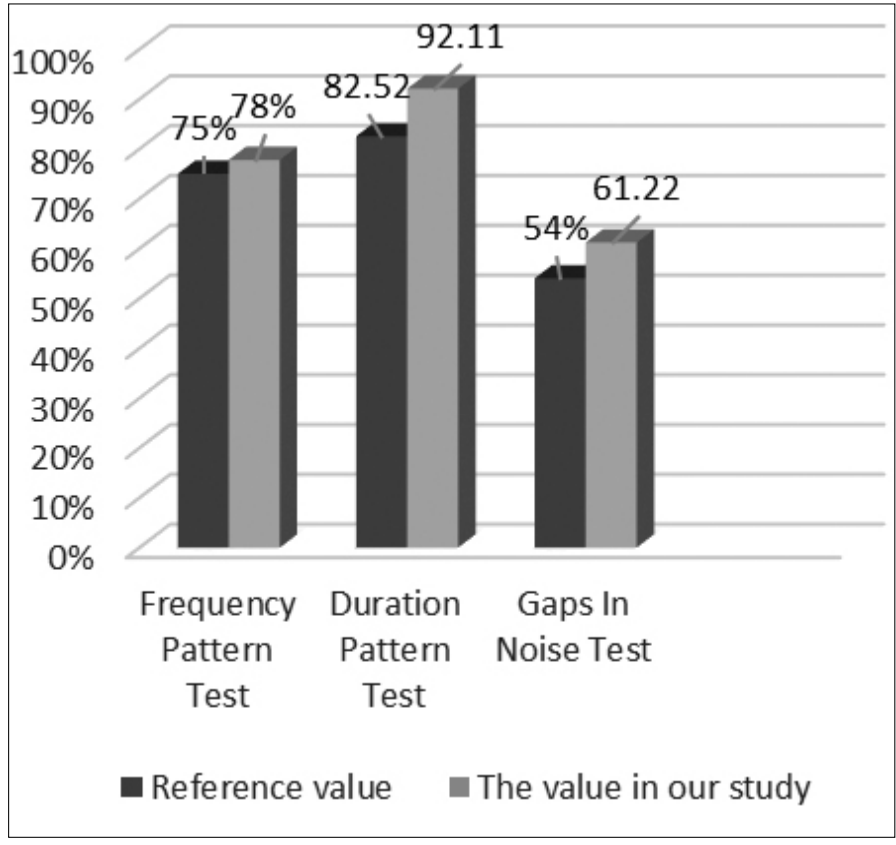

Figure 5. Comparison of The Reference Values With Our Study

FPT: The reference value belongs to normal hearing individuals over the age of 11, (Musiek, 2002).

DPT: The reference value belongs to normal hearing individuals over the age range of 2055, (Gürses, Türkyılmaz, Kalaycıŏlu, et al., 2020).

GIN Test: The values determined by the people who created the GIN test for normal hearing individuals were used as reference (Paulovicks \& Musiek, 2008). 
Table 3. Comparison of FPT Results With Reference Value (75\%) By Age Groups

\begin{tabular}{|l|l|c|c|c|c|c|}
\hline Age Group & & $\mathbf{N}$ & Mean & \pm SD & t & p \\
\hline $\mathbf{2 0 - 3 0}$ & percentage of FPT & 18 & 78.333 & \pm 11.88177 & 1.190 & .250 \\
\hline $\mathbf{3 1 - 4 0}$ & percentage of FPT & 18 & 74.583 & \pm 10.11878 & -.175 & .863 \\
\hline $\mathbf{4 1 - 5 5}$ & percentage of FPT & 16 & 80.468 & \pm 13.42320 & 1.630 & .124 \\
\hline
\end{tabular}

Mean of FPT percentage results by age groups were compared with the reference value of $75 \%$. Since the test probability value of all three age groups (Age Groups 20-30: p:0.250, 31-40: p:0.863, 4155: $\mathrm{p}: 0.124)$ was found $\mathrm{p}>0.05$ in comparison with the reference value, there was no statistically significant difference between the reference value and mean value in our study.

Table 4. Comparison of GIN Test Results With Reference Value (54\%) By Age Groups

\begin{tabular}{|l|l|c|c|c|c|c|}
\hline $\begin{array}{l}\text { Age } \\
\text { Group }\end{array}$ & & $\mathbf{N}$ & Mean & \pm SD & t & p \\
\hline $\mathbf{2 0 - 3 0}$ & Percentage of GIN & 18 & 66.9444 & \pm 9.16176 & 5.994 & $.000^{* *}$ \\
\hline $\mathbf{3 1 - 4 0}$ & percentage of GIN & 18 & 60.3333 & \pm 9.96464 & 2.697 & $.015^{*}$ \\
\hline $\mathbf{4 1 - 5 5}$ & percentage of GIN & 16 & 56.4063 & \pm 5.47485 & 1.758 & .099 \\
\hline
\end{tabular}

The mean of GIN test percentage results by age groups was compared with the reference value of $54 \%$. We compared the reference value and mean value in our study. Since the probability value (Age groups: 20-30: p:0.000**, 31-40: $\left.\mathrm{p}: 0.015^{*}\right)$ was $\mathrm{p}<0.05$, there is a significant difference for the $20-30$ and $31-40$ age groups. The mean of $66.9 \%$ in the $20-30$ age group and $60.3 \%$ in the $31-40$ age group are higher than the reference value of $\% 54$, which was statistically significant. Since the test probability value of the 41-55 age group (p:0.099) was $p>0.05$, there was no statistically significant difference between the reference value of $\% 54$ and mean value in our study.

Table 5. Comparison of GIN Test GDT Results With Reference Value (6 ms) By Age Groups

\begin{tabular}{|l|l|c|c|c|c|c|}
\hline Age Group & & N & Mean & \pm SD & t & P \\
\hline $\mathbf{2 0 - 3 0}$ & GIN threshold value & 18 & 5.7222 & \pm 1.36363 & -.864 & .399 \\
\hline $\mathbf{3 1 - 4 0}$ & GIN threshold value & 18 & 6.5000 & \pm 1.65387 & 1.283 & .217 \\
\hline $\mathbf{4 1 - 5 5}$ & GIN threshold value & 16 & 6.8125 & \pm 1.10868 & 2.931 & $.010^{*}$ \\
\hline
\end{tabular}

**p $<0.01 * \mathrm{p}<0.05$

Mean of GIN test gap detection threshold results by age groups was compared with the reference value. We compared the reference value and mean value in our study. There was no statistically significant difference between the reference value $(6 \mathrm{~ms})$ and mean value in our study since the probability value was higher than 0.05 in the 20-30 and 31-40 age groups (20-30: $\mathrm{p}: 0.399,31-40: \mathrm{p}: 0.217)$. Since the test probability value of the $41-55$ age group ( $\mathrm{p}: 0.010^{*}$ ) was $\mathrm{p}<0.05$, there was a significant difference. The mean value in our study for 41-55 age group is statistically significantly higher than the reference value $(6 \mathrm{~ms})$.
Table 6. Comparison of DPT Results With Reference Value (82.52\%) By Age Groups

\begin{tabular}{|l|l|c|c|c|c|c|}
\hline $\begin{array}{l}\text { Age } \\
\text { Group }\end{array}$ & & $\mathbf{N}$ & Mean & \pm SD & t & p \\
\hline $\mathbf{2 0 - 3 0}$ & percentage of DPT & 18 & 93.0556 & \pm 6.39137 & 6.994 & $.000^{* *}$ \\
\hline $\mathbf{3 1 - 4 0}$ & percentage of DPT & 18 & 89.8611 & \pm 8.55227 & 3.642 & $.002^{*}$ \\
\hline $\mathbf{4 1 - 5 5}$ & percentage of DPT & 16 & 93.4375 & \pm 5.31311 & 8.219 & $.000^{* *}$ \\
\hline
\end{tabular}

$* * \mathrm{p}<0.01 * \mathrm{p}<0.05$

Mean of DPT percentage results by age groups was compared with reference value $(82.52 \%)$. We compared the reference value and mean value in our study. Since the test probability value of all three age groups (Age Groups 20-30: p:0.000**, 31-40: $\left.\mathrm{p}: 0.002^{*}, 41-55: \mathrm{p}: 0.000^{* *}\right)$ was $\mathrm{p}<0.05$, there was a significant difference. The mean values of all age groups is statistically significantly higher than the reference value.

\section{Correlation Between Age and Central Auditory Processing Test Results}

Table 7. Correlation1 Table of CAP Tests And Age

\begin{tabular}{|l|c|c|c|c|c|c|}
\hline No & Variables & $\mathbf{1}$ & $\mathbf{2}$ & $\mathbf{3}$ & $\mathbf{4}$ & $\mathbf{5}$ \\
\hline 1 & Age & 1.000 & & & & \\
\hline 2 & Percentage of FPT & .135 & 1.000 & & & \\
\hline 3 & Percentage of DPT & .093 & $.369 * *$ & 1.000 & & \\
\hline 4 & Percentage of GIN & $-.434 * *$ & .133 & .021 & 1.000 & \\
\hline 5 & GIN threshold value & $.380 * *$ & -.146 & -.028 & $-.928 * *$ & 1.000 \\
\hline
\end{tabular}

A significant correlation was found between GIN test threshold and age $(p<0.05)$. Since the correlation value was found $r=.380$ **, a positive significant correlation was obtained. There is a significant correlation between GIN test percentage and age $(p<0.05)$. There is negative significant correlation because the correlation value was found $\mathrm{r}=-.434 * *$.

\section{DISCUSSION}

In the study of Musiek et al., they stated that FPT and DPT can be applied with earphones as well as in the free-field and do not cause any significant change in the results in individuals with normal hearing or hearing-loss (Musiek, F.E. et al., 2008). Based on this fact, in our study, to evaluate central auditory processing bilaterally at the same time, tests were performed using freefield speaker.

In the application of auditory temporal tests, when the participants were not informed sufficiently about how to perform the test, it caused obtaining low response scores and so incorrect application (Musiek, F.E. et al., 2007). Therefore, in our study, to introduce the application, individuals were instructed at first, and then presented 5-10 stimulus exercises without scoring. In temporal sequencing tests (FPT and DPT), the number of stimuli presentations are generally recommended between 30-50 (Gürses, E. et al., 2020). In our study, 40 triple stimulus patterns were used in FPT and DPT, and 35 sets with gaps were used in the GIN test. 
Other significant factors during the application of Auditory Processing Tests are attention and motivation. Insufficient attention and tiredness of individuals have negative effects on the results (Rawool, V.W., 2016). Considering all three tests in our study, test durations were limited and enough breaks between the tests for not distracting the participants were planned. In the first studies in literature, individuals were requested to express themselves verbally, by humming or pointing in the temporal sequence tests (Musiek, E., 1994). In our study, they were requested to express themselves verbally in FPT and DPT, and by pointing with their fingers in the GIN test. Also the participant were informed that the tests could be stopped when they were distracted or demand to take a break.

The average scores of DPT resulted better than the reference value (see Table 6). The reason for this situation is unclear. However, probably the reason for our such statement is that this test is behavioural and responses depend on the cognitive and the education levels and this may affect the results of temporal sequencing tests. Indeed, the education level may be beneficial for the intellectual development of the individual (Delecrode, C.R. et al., 2014). In the study of Moore et al., a significant correlation was found between auditory processing tests and cognitive skills (Moore, D.R. et al., 2010). Because most of the individuals who participated in our study are academicians or students with high cognitive abilities, high educational and sociocultural levels, it could reflect higher scores especially in DPT. Camarinha et al. investigated, with all aspects, the effects of the levels of education in FPT and DPT on poorly educated workers who lived in rural areas. However, a significant difference between the level of education and FPT, DPT performance could not be found (Camarinha, C.R. et al., 2011).

FPT and DPT require active participation of both brain hemispheres and corpus callosum (Delecrode, C.R. et al., 2014). It has been noted that most of the participants had said more than one of the patterns in reverse (for example; short-long-short instead of the long-short-long pattern or high-low-high instead of low-high-low pattern). It was interpreted as the participants' expressing the patterns in reverse rather than incorrect, perceived the features of the sound correctly, but they were labelling reverse during the verbal expression phase. Yaralı refers to this subject in his study and includes similar interpretations. In addition, he statistically evaluated the expression of patterns in reverse. As a result, the number of patterns in reverse was found significantly lower in musicians than the control group (Yaral1, 2011).

In a study performed on the individuals with normal hearing, they performed better in frequency discrimination than in duration discrimination (Gfeller, K. et al., 2002). According to Bellis et al., DPT is more difficult than FPT and, therefore, normative values are lower for all age groups (Bellis, T.J., 2011). However, Balzan and Tabone on Auditory Temporal Sequencing and Resolution, averages of DPT results were better than FPT results for young adults (18-25) and elders (60-74) for the right and left ears (Balzan, P. et al., 2017). The higher results of DPT in other studies performed in relevant literature are similar to our study (Tuz, D. et al., 2020). Most of the participants in our study performed significantly better in DPT than in FPT, and thus descriptive values of DPT were better in all age groups than in FPT. This situation could be caused by various reasons such as different applications of the methods used in the studies, attention and motivation of the participants during the test.

Actively residing in areas where perception of sound could play an important role such as music, or being related to, could affect performance of the participants who were applied with FPT significantly in this test. Even if not statistically evaluated, subjectively, it was in evidence that the participants who were closely related to music, in our study had better results than others. In the literature, there are studies supporting this opinion. In a study performed by Yaral1, professional musicians performed better in FPT than the control group (Yaral1, 2011). In another study performed by Nascimento et al., musicians and non-musicians were evaluated. It has been found that musicians perform better in FPT for both right and left ears (Nascimento, F.M., 2010).

Musiek accepted the normative value for FPT as $75 \%$ for all our age groups (Musiek, F.E., 2002). In our study, the descriptive value used by Musiek for FPT was considered as a reference of $75 \%$. These averages of the results obtained in FPT by age groups were compared with the reference value and statistically evaluated. These averages in the 20-30 and 41-55 age groups were numerically higher than the reference value and the average is lower than the reference value in the 31-40 age group. The test probability value of all three age groups was considered equal to the reference value of $75 \%$. Although the expression of "Frequency Pattern Test scores are not different than 0.75 ", which is our hypothesis in our study, FPT scores was different from reference value and this difference was not statistically significant.

There are lots of cofactors presented related to DPT in the literature (right-left ear seperation, classification age groups as a wide variety of participant groups (i.e. child, young, adult, elderly adult, etc.) so, it was aimed to use most appropriate study as reference value for our age groups and criteria. Gürses tested DPT normal values in participants who have normal hearing by insert earphones for the control group aged between 18-55 and found it to be $82.52 \%$ (Gürses, E. et al., 2020). For the reasons mentioned above, the reference value was considered as \%82.52 in our study. The average scores obtained in DPT by age groups were compared with the reference value, and statistically evaluated. Although our hypothesis is "Duration Pattern Test scores are not different than 0.82" in our study, DPT scores was different from reference value and this difference was statistically significant. The average score obtained from all three age groups was statistically significantly higher than 
the reference value of $82.52 \%$. A significant difference was found between the results obtained for DPT and the reference value in all three age groups. However, the reference value is a descriptive value not a normative data, so the data obtained in the current study could be better than the reference value.

Paulovicks and Musiek accepted the normative value for the GIN Test as 54\% and the normative value for the gap detection threshold as $6 \mathrm{~ms}$ (Paulovicks, J. et al., 2008). In our study, preceeding normative values were used as reference. The data obtained for the GIN Test were compared with the reference values. The overall test percentage score of the participants in the 20-30 and 31-40 age group was obtained statistically and significantly higher than the reference value. No significant difference was found between the mean value in our study for 41-55 age group and the reference value. When comparing the results obtained for the GIN Test gap detection threshold with the reference value, different results were obtained by the age groups. This difference was not statistically significant for the 20-30 and 31-40 age groups, however the difference for 41-55 age group was statistically significant. However, in the 41-55 age group, the gap detection threshold was $0.8 \mathrm{~ms}$ longer than the reference value compared, and this difference was found statistically significant.

Some studies on temporal resolution revealed that these skills decreased with aging. (Balzan, P. et al., 2017) (Humes, L.E. et al., 2009) (Cesur, S. et al., 2017). Humes et al. found that the gap detection threshold in older adults were significantly higher than in young adults (Humes, L.E. et al., 2009). Cesur and Derinsu investigated the Effect of Aging on Temporal Resolution and revealed that temporal resolution skills decreased with aging (Cesur, S. et al., 2017).

It is observed that temporal abilities decline with aging in individuals with normal hearing (Abel, S.M. et al., 1990). Correlation analysis was performed to evaluate the FPT, DPT and GIN test data obtained in terms of this information. In our analysis to evaluate whether there was a significant correlation between auditory processing tests and age groups. There was not statistically significant correlation between FPT value and age $(\mathrm{p}>0.05)(\mathrm{r}=0.135)$. There was not statistically significant correlation between DPT value and age $(\mathrm{p}>0.05)(\mathrm{r}=0.093)$. As a result of the analyses, a significant correlation was found between the GIN Test percentage and the age factor $(\mathrm{p}<0.05)$. There is negative significant correlation because the correlation value was found $r=-.434 * *$. There was statistically significant correlation between GIN Test threshold value and age $(\mathrm{p}<0.05)$. Since the correlation value was found $\mathrm{r}=.380^{* *}$, a positive significant correlation was obtained. As the age increased, statistically significant decrease in GIN test general score and statistically significant increase in the gap detection threshold were obtained. The accuracy of our hypothesis in terms of GIN test has been observed.
The literature research we performed showed that temporal sequencing tests were generally used collectively. We have utilized temporal sequencing and temporal resolution tests in our study since we have considered its stance as a dependable role in correct diagnosis and emphasized the importance of central auditory processing and test batteries used in its evaluation. We believe this article will contribute to the relevant literature.

\section{CONCLUSION}

Descriptive values that obtained will contribute to the clinics and the literature. The determination of combined data within the young population will encourage researchers to use these tests.

\section{Limitations of Study}

- Subjects were no further evaluated for any speech recognition problems related to CAPD and no further scanning test was utilized.

- The targeted number of participants could not be reached due to the COVID-19 pandemic that affected the world and our country and its negative effects on our lives. Therefore, the study was carried out by the current number of individuals. It is suggested that future studies should be carried out by including more participants. A new study can be done by grouping the participants according to their education level.

Ethics Committee Approval: The study was approved by Non-Interventional Clinical Research Ethics Committee. Approval was obtained for this study with decision number 766 dated with 09/10/201.

Peer-review: Externally peer-reviewed.

Author Contributions: Concept- CY; Design- CY, ENÇ, GK, C YATMAZ, MBŞ; Supervision- MBŞ; Resources- CY, ENÇ, GK, C YATMAZ, MBŞ; Data Collection and/ or Processing- CY, ENÇ, GK, C YATMAZ; Analysis and/or Interpretation- CY, ENÇ, GK; Literature Search- CY, ENÇ, GK; Writing Manuscript- CY, ENÇ, GK.

Conflict of Interest: No conflict of interest.

Financial Disclosure: None.

Etik Kurul Onayı: Çalışma, Girişimsel Olmayan Klinik Araştırmalar Etik Kurulu tarafından onaylandı. Bu çalışma için 09/10/201 tarih ve 766 sayılı karar ile onay alınmıştır.

Hakem Değerlendirmesi: Dış Bağımsız.

Yazar Katkıları: Fikir- CY; Tasarım- CY, ENÇ, GK, C YATMAZ, MBŞ; Denetleme- MBŞ; Kaynaklar- CY, ENÇ, GK, C YATMAZ, MBŞ; Veri Toplanması ve/veya işlemesi- CY, ENÇ, GK, C YATMAZ; Analiz ve/veya Yorum- CY, ENÇ, GK; Literatür Taraması- CY, ENÇ, GK; Yazıyı Yazan- CY, ENÇ, GK.

Çıkar Çatışması: Yoktur.

Finansal Destek: Yoktur.

\section{REFERENCES}

Abel, S. M., Krever, E. M., \& Alberti, P. W. (1990). Auditory detection, discrimination and speech processing in ageing, noise-sensitive and hearingimpaired listeners. Scandinavian Audiology, 19(1), 43-54. https://doi. org/10.3109/01050399009070751

Balzan, P., \& Tabone, N. (2017). Auditory temporal order and resolution in younger and older maltese adults. 3-11. https://doi.org/10.14614/AUDITEMP/8/17

Bellis, T. J. (2011). Assessment And Management Of Central Auditory Processing Disorders In The Educational Setting: from science to practice. In Plural Publishing. Plural Publishing.

Camarinha, C. R., Frota, S. M. M. C., Pacheco-Ferreira, H., \& De Lima, M. A. de M. T. (2011). Auditory temporal processing assessment in rural workers exposed to organophosphate pesticides. Jornal Da Sociedade Brasileira de Fonoaudiologia, 23(2), 102-106. https://doi.org/10.1590/S2179-64912011000200004 
Cesur, S., \& Derinsu, E. U. (2017). Effect of aging on temporal resolution. Turkish Journal of Geriatrics, 20(3), 178-186.

Delecrode, C. R., Cardoso, A. C. V., Frizzo, A. C. F., \& Guida, H. L. (2014). Pitch Pattern Sequence And Duration Pattern Test's in Brazil: Literature Review. Revista CEFAC, 16(1), 283-293. https://doi.org/10.1590/1982-021620143912

Erdfelder, E., FAul, F., Buchner, A., \& Lang, A. G. (2009). Statistical power analyses using $G^{*}$ Power 3.1: Tests for correlation and regression analyses. Behavior Research Methods, 41(4), 1149-1160. https://doi.org/10.3758/BRM.41.4.1149

Fattahi, J., Tahaei, A. A., Ashayeri, H., Mohammadkhani, G., \& Jalaie, S. (2019). Evaluation of central auditory processing of azeri-persian bilinguals using dichotic listening tasks in first and second languages. Iranian Journal of Child Neurology, 13(1), 79-90.

Fitzgibbons, P. J., \& Gordon-Salant, S. (1996). Auditory temporal processing in elderly listeners. Journal of the American Academy of Audiology, 7(3).

Geffner, D., \& Ross-Swain, D. (2007). Central Auditory Processing Disorders: definition, description, behaviors and comorbitidies. In Auditory Processing Disorders-Assesment, Management, and Treatment (3rd ed., p. s. 38-39). Plural Publishing.

Gfeller, K., Turner, C., Mehr, M., Woodworth, G., Fearn, R., Knutson, J. F., ... Stordahl, J. (2002). Recognition of familiar melodies by adult cochlear implant recipients and normal-hearing adults. Cochlear Implants International, 3(1), 29-53. https://doi.org/10.1179/cim.2002.3.1.29

Gilani, V. M., Ruzbahani, M., Mahdi, P., Amali, A., Khoshk, M. H. N., Sameni, J., ... Emami, H. (2013). Temporal processing evaluation in tinnitus patients: Results on analysis of gap in noise and duration pattern test. Iranian Journal of Otorhinolaryngology, 25(73), 221-225. https://doi.org/10.22038/ ijorl.2013.1951

Göv Aktan, K. (2015). Eğitim Ortamında Dinleme Becerileri Envanteri (Revize Edilmiș)'nin Normalizasyonu. Başkent Üniversitesi Sağlık Bilimleri Enstitüsü.

Gürses, E., Türkyılmaz, M. D., Kalaycığlu, C., Karabulut, E., Bajin, M. D., Sennaroğlu, L., \& Genç, G. A. (2020). Evaluation of temporal and suprasegmental auditory processing in patients with unilateral hearing loss. Auris Nasus Larynx, 47(5), 785-792. https://doi.org/10.1016/j.anl.2020.04.009

Gürses, E., Türkyılmaz, M. D., \& Sennaroğlu, G. (2020). Evaluation of auditory temporal processing in patients fitted with bone-anchored hearing aids. European Archives of Oto-Rhino-Laryngology, 277(2), 351-359. https://doi. org/10.1007/s00405-019-05701-4

Hoover, E., Pasquesi, L., \& Souza, P. (2015). Comparison of clinical and traditional gap detection tests. Journal of the American Academy of Audiology, 26(6), 540-546. https://doi.org/10.3766/jaaa.14088

Humes, L. E., Busey, T. A., Craig, J. C., \& Kewley-Port, D. (2009). The effects of age on sensory thresholds and temporal gap detection in hearing, vision, and touch. Attention, Perception, and Psychophysics, 71(4), 860-871. https://doi. org/10.3758/APP.71.4.860

Jung, Y. K., \& Lee, J. H. (2020). Gaps-In-Noise Test Performance in Children with Speech Sound Disorder and Cognitive Difficulty. Journal of Audiology and Otology, 24(3), 133-139. https://doi.org/10.7874/jao.2019.00381

Long, P., Wan, G., Roberts, M. T., \& Corfas, G. (2018, February 1). Myelin development, plasticity, and pathology in the auditory system. Developmental Neurobiology, Vol. 78, pp. 80-92. John Wiley and Sons Inc. https://doi. org/10.1002/dneu.22538
Marshall, E. K., \& Jones, A. L. (2017). Evaluating test data for the duration pattern test and pitch pattern test. Speech, Language and Hearing, 20(4), 241-246. https://doi.org/10.1080/2050571X.2016.1275098

Moore, D. R., Ferguson, M. A., Edmondson-Jones, A. M., Ratib, S., \& Riley, A. (2010). Nature of auditory processing disorder in children. Pediatrics, 126(2). https://doi.org/10.1542/peds.2009-2826

Musiek, F. E. (1994). Frequency (pitch) and duration pattern tests. In J Am Acad Audiol (Vol. 5).

Musiek, F. E. (2002). The frequency pattern test. The Hearing Journal, 55(6), 58. https://doi.org/10.1097/01.HJ.0000293280.99394.dd

Musiek, F. E., Pinheiro, M. L., \& Wilson, D. H. (2008). Auditory pattern perception in "Split Brain" patients. Archives of Otolaryngology, 106(10), 610-612. https:// doi.org/10.1001/archotol.1980.00790340018004

Musiek, F. E., Shinn, J. B., Jirsa, R., Bamiou, D.-E., Baran, J. A., \& Zaida, E. (2005) GIN (Gaps-In-Noise) Test performance in subjects with confirmed central auditory nervous system involvement. Ear and Hearing, 26(6), 608-618. https://doi.org/10.1097/01.aud.0000188069.80699.41

Musiek Frank E., \& Chermak Gail D. (2007). Handbook Of (Central) Auditory Processing Disorders, Vol. 1: Auditory Neuroscience And Diagnosis (1 edition). San Diego, CA: Plural Publishing Inc.

Mustek, F. E., Baran, J. A., \& Pinheiro, M. L. (1990). Duration pattern recognition in normal subjects and patients with cerebral and cochlear lesions. International Journal of Audiology, 29(6), 304-313. https://doi org/10.3109/00206099009072861

Nascimento, F.M., Monteiro, R.A.M., Soares, C.D., F. (2010). Temporal resolution abilities in musicians and no musicians violinists. International Archives Otolaryngology, 14(2), 217-224.

Paulovicks, J., \& Musiek, F. E. (2008). The gaps-in-noise (GIN) test and its diagnostic significance. Hearing Journal, 61(3), 67. https://doi.org/10.1097/01. HJ.0000314723.80439.72

Rawool, V. W. (2016). Auditory Processing Deficits : assessment and intervention. In Auditory Temporal Processing Assessment (pp. 57-122). Stuttgart Germany: Thime.

Shinn, J. B., Chermak, G. D., \& Musiek, F. E. (2009). GIN (Gaps-In-Noise) performance in the pediatric population. Journal of the American Academy of Audiology, 20(4), 229-238. https://doi.org/10.3766/jaaa.20.4.3

Tuz, D., Aslan, F., Böke, B., \& Yücel, E. (2020). Assessment of temporal processing functions in early period cochlear implantation. European Archives of OtoRhino-Laryngology, 277(7), 1939-1947. https://doi.org/10.1007/s00405-02005935-7

Volpatto, F. L., Rechia, I. C., Lessa, A. H., Soldera, C. L. C., Ferreira, M. I. D. da C., \& Machado, M. S. (2019, January). Questionnaires and checklists for centra auditory processing screening used in Brazil: a systematic review. Brazilian Journal of Otorhinolaryngology, Vol. 85, pp. 99-110. Elsevier Editora Ltda. https://doi.org/10.1016/j.bjorl.2018.05.003

Yaralı, M. (2011). Profesyonel müzisyenlerde santral ișitsel ișlemleme becerilerinin değerlendirilmesi. Hacettepe Üniversitesi.

Zhang, G. W., Sun, W. J., Zingg, B., Shen, L., He, J., Xiong, Y., ... Zhang, L. I. (2018). A Non-canonical reticular-limbic central auditory pathway via medial septum contributes to fear conditioning. Neuron, 97(2), 406-417.e4. https://doi. org/10.1016/j.neuron.2017.12.010 